九州大学学術情報リポジトリ

Kyushu University Institutional Repository

\title{
Innate cell-mediated cytotoxicity of CD8+ T cells against the protozoan parasite Ichthyophthirius multifiliis in the ginbuna crucian carp Carassius auratus langsdorfi i
}

Sukeda, Masaki

Laboratory of Marine Biochemistry, Department of Bioscience and Biotechnology, Graduate School of Bioresource and Bioenvironmental Sciences, Kyushu University

Shiota, Koumei

Laboratory of Marine Biochemistry, Department of Bioscience and Biotechnology, Graduate School of Bioresource and Bioenvironmental Sciences, Kyushu University

Kondo, Masakazu

Department of Applied Aquabiology, National Fisheries University, Japan Fisheries Research and Education Agency

Nagasawa, Takahiro

Laboratory of Marine Biochemistry, Department of Bioscience and Biotechnology, Graduate School of Bioresource and Bioenvironmental Sciences, Kyushu University : Assistant Professor

他

http://hdl. handle. net/2324/4113184

出版情報：Developmental \& Comparative Immunology. 115 (103886)，2021-02. Elsevier バージョン：

権利関係 : 
1 Innate cell-mediated cytotoxicity of $\mathrm{CD8}^{+} \mathbf{T}$ cells against the protozoan parasite

8 aaboratory of Marine Biochemistry, Department of Bioscience and Biotechnology,

9 Graduate School of Bioresource and Bioenvironmental Sciences, Kyushu University,

10 Fukuoka 819-0395, Japan

$11{ }^{\text {b}}$ Department of Applied Aquabiology, National Fisheries University, Japan Fisheries

12 Research and Education Agency, Shimonoseki, Yamaguchi 759-6595, Japan

13

*Corresponding author: Tomonori Somamoto

Phone: (81)-92-802-4792; Fax: (81)-92-802-4791

E-mail: somamoto@agr.kyushu-u.ac.jp

18 
47

\section{Abstract}

Cytotoxic T cells are known to have the ability to kill microbe-infected host cells, which makes them essential in the adaptive immunity processes of various vertebrates. In this study, we demonstrated innate cell-mediated cytotoxicity of $\mathrm{CD}^{+} \mathrm{T}$ cells against protozoan parasites found in the ginbuna crucian carp. When isolated effector cells such as $\mathrm{CD}^{+}, \mathrm{CD}^{+}\left(\mathrm{CD} 4-1^{+}\right)$, or $\mathrm{CD}^{-} \mathrm{CD}^{-}$(double-negative, $\left.\mathrm{DN}\right)$, from naïve ginbuna crucian carp were co-incubated with target parasites (Ichthyophthirius multifiliis), $\mathrm{CD}^{+}$ cells from the kidney and gill showed the highest cytotoxic activity. On the other hand, DN cells, which include macrophages and $\mathrm{CD}^{-} \mathrm{CD}^{-}$lymphocytes, showed the lowest cytotoxic activity against $I$. multifiliis. Additionally, the cytotoxic activity of $\mathrm{CD}^{+}$cells was found to significantly decrease in the presence of a membrane separating the effector cells from I. multifiliis. Furthermore, the serine protease inhibitor 3,4dichloroisocoumarin and perforin inhibitor concanamycin A significantly inhibited the cytotoxic activity of $\mathrm{CD} 8^{+}$cells. These results demonstrate that $\mathrm{CD} 8^{+} \mathrm{T}$ cells of ginbuna crucian carp can kill extracellular parasites in a contact-dependent manner via serine proteases and perforin. Therefore, we conclude that $\mathrm{CD} 8^{+} \mathrm{T}$ cells play an essential role in anti-parasite innate immunity of teleost fish.

Key words: Cytotoxic activity; $\mathrm{CD}^{+} \mathrm{T}$ cells; I. multifiliis; extracellular parasites; ginbuna crucian carp 8 


\section{Introduction}

In mammals, $\mathrm{CD} 8^{+}$cytotoxic $\mathrm{T}$ cells (CTLs) are considered the primary cytotoxic cells in adaptive immunity, and they require antigen pre-sensitization to gain the ability to kill target cells, such as viral or intracellular bacterial-infected cells, tumor cells, and allogeneic cells. It has already been reported that antigen-specific cell-mediated cytotoxicity $(\mathrm{CMC})$ can be induced in teleost $\mathrm{CD} 8^{+}$cells by sensitization with alloantigen and viral antigen, and they presumably recognize virus-infected cells in a major histocompatibility complex (MHC) class I restricted-manner (Somamoto et al., 2015, 2014; Yamaguchi et al., 2019). These findings show that CTLs play an essential role in the adaptive cell-mediated immunity of teleosts, similar to mammalian CTLs.

Ichthyophthirius multifiliis has been identified as a ciliated protozoan that infects freshwater fishes and causes white spot disease (Buchmann et al., 2001; Cross and Matthews, 1993). I. multifiliis has a life cycle that consists of four stages: theront, trophont, tomont, and cyst (Dickerson, 2006; Wang et al., 2019). Because it is easy to obtain these pathogens from diseased fish and to artificially infect recipient fish, immune responses to I. multifiliis represent an excellent model in elucidating the immune system of fish against extracellular parasites (Cassidy-Hanley et al., 2011; Coyne et al., 2011; Xu and Klesius, 2013). Innate humoral immune factors such as chemokines and complement components are involved in the protection of several fish species from parasitic infection, including channel catfish (Ictalurus punctatus), carp (Cyprinus carpio), and rainbow trout (Oncorhynchus mykiss) (Cross and Matthews, 1993; Dickerson and Clark, 1998; Olsen et al., 2011). Antibody-secreting cells from fish immunized with I. multifiliis produce IgM or IgT that specifically bind trophonts (Von Gersdorff Jørgensen et al., 2011; Yu et al., 2018). Antibodies recognize most glycosylphosphatidylinositol (GPI)-anchored surface 
membrane proteins to resemble the immobilization antigen (i-antigen) of the free-living ciliates and interfere with ciliary beat, leading to immobilization of the parasite (Clark and Forney, 2003). This suggests that antibodies contribute to the elimination of parasites. These studies on immune responses to I. multifiliis mainly focus on the humoral immune factors, while information on cell-mediated immunity against parasites is limited. Nonspecific cytotoxic cells (NCCs), which were first identified in channel catfish, are the only known anti-parasitic cytotoxic cells in teleost fishes (Graves et al., 1985; JasoFriedmann et al., 1997). The anti-parasitic abilities of NCCs suggest that cell-mediated immunity is an effective defense mechanism against parasites in teleost fish.

In mammals, $\mathrm{CD}^{+}$and $\mathrm{CD} 8^{+} \mathrm{T}$ cells have innate cytotoxic activity against various types of pathogens, including bacteria, fungi, and parasites. CTLs have direct antibacterial activity that can kill extracellular bacteria in mice (Mody and Oykhman, 2010). Furthermore, murine CTLs were shown to exhibit fungicidal activity against the fungus Candida albicans and inhibited its growth (Beno et al., 1995; Beno and Mathews, 1992). In addition, human CTLs stimulated with phytohemagglutinin (PHA) killed the multicellular parasites Schistosoma mansoni and Entamoeba histolytica, and the cytotoxic activity was dependent on contact with the target pathogens (Ellner et al., 1982; Salata et al., 1987). We have previously shown that $\mathrm{CD} 8^{+}$cells from ginbuna crucian carp exhibit direct cytotoxic ability against the bacteria Lactococcus garvieae and Edwardsiella tarda, suggesting that fish CTLs have the ability to recognize target cells in a manner independent of the T cell receptor (TCR) (Nayak and Nakanishi, 2013). These findings further suggest a possibility that fish CTLs possess innate cytotoxic activity toward various types of pathogens, in addition to self-infected and allogeneic cells. In the present study, we aimed to demonstrate that $\mathrm{CD} 8^{+} \mathrm{T}$ cells possess natural cytotoxic 
ability against theronts of I. multifiliis and describe the cytolytic mechanisms involved. Our findings provide an important insight into anti-parasite immunity and the evolution of cell-mediated immunity.

\section{Materials and Methods}

\subsection{Fish}

Ginbuna crucian carps (Carassius auratus langsdorfii [OB1 clone]) were hatched from the National Fisheries University and reared at Kyushu University. Adult ginbuna crucian carps weighing approximately $23.2 \mathrm{~g}$ were used in this study. Fish were kept in 140-L tanks at $25 \square$ with running water; they were fed daily with commercial pellets (Nippon Formula Feed Manufacturing Co., Ltd.). Spontaneous occurrence of white spot disease was not observed in these experimental fish. All experiments involving fish were performed in accordance with the guidelines of the Animal Experiments Committee at Kyushu University.

\subsection{Preparation of I. multifiliis}

It has been reported that only few of artificially exposed theronts can transform into mature trophonts, which suggests that most invading theronts are eliminated before they become mature trophonts (Xu et al., 2004; unpublished observation). Therefore, we focused on the immune response at this stage of I. multifiliis and used theronts as the target in this study. The parasite strains used in the present study originated from infected fish obtained from Kyorin Co., Ltd. and ornamental fish shops in Fukuoka city. They were identified as I. multifiliis by microscopy and polymerase chain reaction (PCR) using 

mature parasitic trophonts were anesthetized with 5\% 2-methylquinoline in EtOH and rinsed with water. The anesthetized fish were placed on petri dishes with pure water, and the skin was gently scraped with a cell scraper to collect the trophonts (Zellschaber; Techno Plastic Products AG., Trasadingen, Switzerland). To collect live theronts, the isolated trophonts were transferred to a beaker filled with water. To avoid contaminating the mucus, trophonts were replaced in a beaker with fresh pure water and were then incubated for $18 \mathrm{~h}$ at $20^{\circ} \mathrm{C}$ (Xu et al., 2009). Alternatively, live theronts were collected from water in an aquarium with I. multifiliis-infected fish. To remove large impurities, theronts were passed through a sieve with a pore size of $37 \mu \mathrm{m}$ (ITOH SEISAKUSHO CO., Tokyo, Japan). The theronts were concentrated by centrifugation at $100 \times \mathrm{g}$ for 5 min and suspended in $800 \mu$ l of RPMI-1640 medium (Nissui Pharmaceutical Co., Tokyo, Japan) supplemented with $0.5 \%$ heat-inactivated fetal bovine serum (Biowest, France). Theronts were counted using an optical plastic plankton counter (MATSUNAMI., Osaka, Japan).

\subsection{Preparation of the effector cells}

138 Fish were anesthetized with 5\% 2-methylquinoline in $\mathrm{EtOH}$ and dissected to isolate the 139 trunk and head kidneys and gills. Leukocytes from both the kidneys and the gills of 140 ginbuna carp were prepared by aseptically disaggregating the tissue through a sterilized 150-gauge mesh stainless steel sieve in RPMI-1640 medium. Leukocyte suspensions were then layered over a Percoll density gradient (1.08 g/ml, GE Healthcare), followed by centrifugation at $330 \times \mathrm{g}$ for $25 \mathrm{~min}$ at $4^{\circ} \mathrm{C}$. Leukocytes on the Percoll gradient were collected and washed twice with RPMI-1640. T cell subsets (CD8 $\alpha^{+}$and CD4 ${ }^{+}$cells) were 

using anti-ginbuna CD8 $\alpha$ and CD4 (CD4-1) monoclonal antibodies (MAbs) according to the method described by Toda et al. (2011b). In brief, a suspension of kidney and gill cells in RPMI-1640 medium was incubated with 1:10000 rat anti-ginbuna CD8 $\alpha$ MAb (2C3: mouse ascites) for $40 \mathrm{~min}$ on ice. The cells were then washed thrice with RPMI-1640, incubated for $20 \mathrm{~min}$ at $4^{\circ} \mathrm{C}$ with $100 \mu \mathrm{l}$ of a 1:5 dilution of magnetic bead-conjugated goat anti-rat IgG antibody (Miltenyi Biotec GmbH, Germany), and washed three times.

CD8 $\alpha$-positive and CD8 $\alpha$-negative cells were then separated using MACS by applying the cell suspension to a plastic column equipped with an external magnet. CD8 $\alpha^{+}$cells were retained in the column, whereas the $\mathrm{CD} 8 \alpha^{-}$cells were not. $\mathrm{CD} 8 \alpha^{-}$cells were further separated into $\mathrm{CD}^{+}$and $\mathrm{DN}$ fractions using rat-anti-ginbuna CD4-1 MAb (6D1) according to the method described above.

\subsection{RT-PCR analysis of MACS-sorted cells}

Total RNA was extracted from $5.0 \times 10^{5}$ sorted cells of each cell population using a

160 NucleoSpin ${ }^{\circledR}$ RNA kit (TaKaRa, Japan) and reverse transcribed into cDNA using MMLV Reverse Transcriptase (NIPPON GENE) with Oligo d(T) 16 primers. Specific primer sets for CD4-1, CD8 $\alpha, \mathrm{TCR} \beta, \mathrm{TCR} \gamma, \mathrm{Lck}$, and EF1- $\alpha$ were used for RT-PCR, as shown in Table 1 (Barreda et al., 2005; Matsuura et al., 2014; Miyazawa et al., 2018; Nonaka et al., 2008; Toda et al., 2011b, 2011a; Accession.No, NC_039269.1.). The PCR conditions were as follows: one cycle of $95^{\circ} \mathrm{C}$ for $2 \mathrm{~min}, 30-37$ cycles of $95^{\circ} \mathrm{C}$ for $10 \mathrm{~s}, 60^{\circ} \mathrm{C}$ for 10 $\mathrm{s}$, and $72^{\circ} \mathrm{C}$ for $30 \mathrm{~s}$. The PCR reactions were performed in $24.5-\mu 1$ reaction mixtures containing 10× Ex Taq Buffer, dNTP Mixture (2.5 mM each), $1.0 \mu \mathrm{M}$ of each primer, TaKaRa Ex Taq (5 units/ $\mu$ ) (TaKaRa, Japan), and $0.5 \mu$ of cDNA template. The PCR 
products were electrophoresed in $1.3 \%$ agarose gels and visualized by staining the gel with $0.5 \mu \mathrm{g} / \mathrm{ml}$ ethidium bromide (Wako, Japan). Images of the PCR products were photographed using Gel Scene Tablet (ASTEC, Japan).

2.5. Cytotoxic activity of unsorted leukocytes, $\mathrm{CD8}^{+}, \mathrm{CD4}^{+}$, and $\mathrm{DN}$ cells against $\mathrm{I}$.

\section{multifiliis}

Unsorted leukocytes were mixed with 300 I. multifiliis cells in RPMI-1640 medium in 96-well plates at effector/target cell ratios (E:T) of 2000:1, 1000:1, 300:1, or 100:1. Next, they were incubated at $20^{\circ} \mathrm{C}$ for 2,4 , and $6 \mathrm{~h}$. After incubation, dead I. multifiliis were stained with $0.2 \%$ trypan blue (Wako, Japan). The stained I. multifiliis were counted on plankton number count boards (MATSUNAMI, Japan, Osaka) under a microscope to calculate the cytotoxic activity of leukocytes against I. multifiliis (Ahmadpour et al., 2019). Parasites that spontaneously died in the medium were also counted in the negative control. The cytotoxic activity was calculated using the following formula and indicated by percentage (Ellner et al., 1982):

Cytotoxic activity $(\%)=\{100 \times[$ (Number of dead I. multifiliis in test group $)-($ Number of dead I. multifiliis in negative control)] / [(Total number of I. multifiliis in test group) (Number of dead I. multifiliis in negative control)]\}

To identify the anti-parasite effector cell population, unsorted or $\mathrm{CD} 8^{+}, \mathrm{CD} 4^{+}$, or $\mathrm{DN}$ cells were adjusted at effector/target cell ratios (E:T) of 1000:1 and then incubated for 2 h. The cytotoxic activity was measured and calculated as described above. 
194 Leukocytes from the kidney and gill were prepared according to the method described

195 above. Leukocytes in RPMI-1640 medium were incubated with 1:10 ${ }^{4}$ rat anti-ginbuna $196 \mathrm{CD} 8 \alpha \mathrm{MAb}(2 \mathrm{C} 3)$ for $40 \mathrm{~min}$ on ice. To label $\mathrm{CD}^{+}$cells, the cells were washed three 197 times with medium and were further incubated for $30 \mathrm{~min}$ at $4{ }^{\circ} \mathrm{C}$ with anti-rat $\operatorname{IgG}$ 198 conjugated with PE (BioLegend, USA, State of California, San Diego). I. multifiliis that 199 were incubated with $1 \quad \mathrm{mg} / \mathrm{mL} \quad$ 3',6'-di(O-acetyl)-4',5'-bis[N,N200 bis(carboxymethyl)aminomethyl] fluorescein tetraacetoxymethylester (DOJINDO, 201 Japan) diluted 1:50 for 30 min were washed three times with water and suspended in RPMI-1640 medium. Leukocytes $\left(3.0 \times 10^{5}\right.$ cells $)$ and I. multifiliis $(300$ cells $)$ were added to RPMI-1640 medium in 96-well plates at E:T ratios of 1000:1 and then incubated at $20^{\circ} \mathrm{C}$ for $2 \mathrm{~h}$. After incubation, each sample was observed using fluorescence microscopy (Leica).

\subsection{Cytotoxicity assay of effector cells using Transwell inserts}

To determine whether the cytotoxic activity of each population of effector cells $\left(\mathrm{CD}^{+} \mathrm{T}\right.$ cells, $\mathrm{CD} 8^{-}$cells) required contact to the target parasites, 12-mm Transwell ${ }^{\circledR}-\mathrm{COL}$

210 Collagen-Coated $0.4 \mu \mathrm{m}$ Pore PTFE Membrane Inserts (Corning, USA, State of New

211 York, Corning) were used, as described by Haitham et al. (Tartor et al., 2014). Briefly, a $100 \mu \mathrm{L}$ aliquot containing $300 \mathrm{I}$. multifiliis cells was added to the upper compartment of the tissue culture inserts, and a $200 \mu \mathrm{L}$ aliquot containing $1.5 \times 10^{5}$ effector cells was added to the lower compartment of a 12-well plate well. The two compartments were separated by a membrane with a pore size of $0.4 \mu \mathrm{m}$. The plates were then incubated at $22^{\circ} \mathrm{C}$ for $2 \mathrm{~h}$. After incubation, $100 \mu \mathrm{L}$ of the culture suspension was collected from the upper compartment. Dead I. multifiliis were counted to determine the percentage of 
218 killing activity as described above. As a negative control, a $100 \mu \mathrm{L}$ aliquot containing 300

219 I. multifiliis cells was added to the upper compartment of the tissue culture inserts, and $220200 \mu \mathrm{L}$ of cell-free RPMI-1640 medium was added to the lower compartment of a 12221 well plate.

\subsection{Effect of perforin and serine protease inhibitors on cytotoxicity}

224 The effect of perforin or serine protease inhibitors on the cytotoxic activity of each 225 effector cell population $\left(\mathrm{CD}^{+}\right.$cells and $\mathrm{CD} 8^{-}$cells) was examined using concanamycin A (CMA, Sigma, St. Louis MO) or 3,4-dichloroisocoumarin (DCI, Sigma, St. Louis MO, USA), respectively. Each effector cell was separated from the gill and kidney of ginbuna carp as described above. Effector cells were treated with CMA at two concentrations (1 and $0.5 \mu \mathrm{M})$ for $2 \mathrm{~h}$ or DCI at two concentrations (40 and $20 \mu \mathrm{M})$ for $3 \mathrm{~h}$ at $22^{\circ} \mathrm{C}$. The concentrations of these inhibitors were determined according to previous studies, and untreated effector cells were used as a control (Toda et al., 2011a, 2011c). The inhibitortreated effector cells $\left(9.0 \times 10^{4}\right.$ cells $)$ were then co-cultured with 300 I. multifiliis cells per well in 96-well plates in the presence of inhibitors for $2 \mathrm{~h}$ at $22^{\circ} \mathrm{C}$. Dead parasites were then counted in each treated group at all inhibitor concentrations, and the percentage of dead cells was then calculated using the above formula, accounting for negative controls. The percentage of killing activity was calculated as described.

\subsection{Statistics}

Differences among the four groups were compared using the Kruskal-Wallis test. The Mann-Whitney $U$ test was used to determine significant differences between the two groups. Steel's multiple comparison test was used to analyze the effects of perforin and 
serine proteases inhibitors on cytotoxicity. $\mathrm{P}$ values less than 0.05 were considered statistically significant.

\section{Results}

\subsection{Expression of $T$ cell-related molecules in effector cells}

To characterize the effector cells in the kidney and gills, we examined the expression profile of T cell-related molecules (Fig. 1). In both the kidney and gill, $2 \mathrm{C} 3^{+}$lymphocytes strongly expressed CD8 $\alpha, \mathrm{TCR} \beta$, and Lck, indicating that they were primarily composed of $\mathrm{CD}^{+} \mathrm{T}$ cells. Although $6 \mathrm{D} 1^{+}$lymphocytes from the kidney showed high expressions of CD4-1 and Lck, the same level of expression of CD8 mRNA was detected in this cell population from gills. This tendency was also observed in $\mathrm{CD}^{+}$cells from the gills of each individual fish. Thus, although the possibility that $\mathrm{CD}^{+}$cells were contaminated in this cell population cannot be excluded, a small population of CD8 and CD4 doublepositive cells may exist in the gill. In the kidney cell population, DN leukocytes exhibited higher expression of $\mathrm{TCR} \gamma$ than $\mathrm{CD}^{+}$and $\mathrm{CD} 4^{+}$cells. In contrast, $\mathrm{CD} 8^{+}$cells from gills showed the highest expression of TCR $\gamma$, suggesting that $\mathrm{CD} 8^{+} \mathrm{TCR} \gamma \delta \mathrm{T}$ cells are present in the gills of ginbuna crucian carp.

3.2. Time course of cytotoxic activity of leukocytes against $I$. multifiliis at different effector and target ratios

Kidney and gill leukocytes demonstrated cytotoxic activity against I. multifiliis (Fig. 2). The cytotoxic activities at E:T ratios of 2000:1, 1000:1, and 300:1 were detected at $2 \mathrm{~h}$ and increased with incubation time. The activities at the E:T ratio of 100:1 were lower than $20 \%$ at all incubation times. The cytotoxic activity was increased in an effector/target 
ratio-dependent manner, and the highest activities were detected at E:T ratios of 2000:1 and 1000:1. No notable difference was observed in cytotoxic activity between leukocytes isolated from the kidney and those isolated from the gill.

\subsection{Characterization of dominant effector cells against $I$. multifiliis}

$\mathrm{CD}^{+}$cells from the kidney and gill exhibited the highest cytotoxic activity against $I$. multifiliis among all analyzed cells (Fig. 3). Meanwhile, DN cells from the kidney and gill showed the lowest cytotoxic activity. The cytotoxic activity of $\mathrm{CD}^{+}$cells from both organs was significantly higher than that of the unsorted cells, $\mathrm{CD}^{+}$cells, and DN cells (Figs. 3A and B). CD4 ${ }^{+}$cells from the gill showed significantly higher activity than DN cells (Fig. 3B). The effector cells from both kidney and gill showed similar levels of cytotoxic activity. These results show that $\mathrm{CD} 8^{+}$cells can directly recognize and kill $I$. multifiliis.

\section{4. $\mathrm{CD8}^{+}$cells bound to I. multifiliis}

Kidney and gill $\mathrm{CD}^{+}$cells physically interacted with the surface of I. multifiliis cells (Fig. 4). $\mathrm{CD}^{+}$cells from the kidney, which were bound to the parasites, exhibited lymphocyte morphology. The parasites that came into contact with $\mathrm{CD}^{+}$cells ceased movement activity, but other parasites moved vigorously during our observation. The activities of parasites that interacted with $\mathrm{CD}^{+}$cells gradually decreased during incubation. These results indicate that $\mathrm{CD} 8^{+} \mathrm{T}$ cells can directly recognize and kill I. multifiliis.

\subsection{Requirement of effector cell-target contact for killing of I. multififiliis}

In the presence of a membrane separating effector cells from I. multifiliis, the cytotoxic 
activity of $\mathrm{CD}^{+}$cells from the kidneys and gills against the target parasite was significantly reduced, whereas that of $\mathrm{CD}^{-}$cells from the kidneys and gills was not decreased (Fig. 5). These results suggest that $\mathrm{CD} 8^{+}$effector cells require direct contact with the parasite surface to exhibit cytotoxic effects.

\subsection{Effect of perforin and serine protease inhibitors on cytotoxicity against $I$.} multifiliis

The cytotoxic activities of $\mathrm{CD} 8^{+}$cells from kidney and gill were inhibited by the addition of 20 or $40 \mu \mathrm{M}$ DCI (Fig. 6). This suggested that $\mathrm{CD}^{+}$cells kill I. multifiliis using serine proteases such as granzymes.

The cytotoxic activity of $\mathrm{CD}^{+}$cells from the kidney treated with $1 \mu \mathrm{M}$ of CMA was significantly lower than that of the untreated cells (Fig. 7). There was no significant difference in the activity of $\mathrm{CD}^{+}$cells from the gills, whereas the mean percentage of CMA-treated effector cells was lower than that of untreated cells. These results indicate that $\mathrm{CD}^{+}$cells kill I. multifiliis in a manner dependent on the activity of perforin and serine proteases.

\section{Discussion}

308 CMC is an important defense mechanism for eliminating targets such as host cells infected with virus or intracellular bacteria and tumor cells in both mammals and teleost fish. Although previous studies identifying cytotoxic cells using clonal ginbuna crucian carp have demonstrated antigen-specific $\mathrm{CMC}$ of $\mathrm{CD} 8^{+}$cells against allogeneic and virusand bacteria-infected syngeneic cells (Somamoto et al., 2006; Toda et al., 2009; Yamasaki et al., 2014), no studies have reported anti-parasite cytotoxicity in this species. Several 
314 types of natural killer (NK)-like cells including NCC have already been identified in 315 teleost fish (Fischer et al., 2013). However, the innate CMC of CD8 ${ }^{+}$cells remains to be reported in any fish species. In the present study, we showed that $\mathrm{CD} 8^{+}$cells from nonsensitized effectors are the primary cytotoxic effector cells against protozoan parasites, suggesting that $\mathrm{CD} 8^{+} \mathrm{T}$ cells are important effector cells in anti-parasite innate immunity of teleost fish. This finding provides a novel insight into the evolution of cytotoxic cells and further contributes to the understanding of anti-parasite immunity of teleost fish. $\mathrm{CD} 8^{+}$and $\mathrm{CD} 4^{+}$cells showed significant cytotoxic activity against I. multifiliis, whereas DN cells showed the lowest cytotoxic activity. In particular, $\mathrm{CD} 8^{+} \mathrm{T}$ cells were identified as the main effector cells against I. multifiliis in ginbuna crucian carp. Studies have demonstrated that $\mathrm{CD}^{+}$and $\mathrm{CD} 4^{+}$cells from fish immunized with bacteria can kill the bacteria without the need for presentation of target antigens (Nayak and Nakanishi, 2013). The present study showed that $\mathrm{CD}^{+}$cells from naïve fish possess cytotoxic activity against parasites and can also recognize and kill target cells without any stimulation. These findings suggest that $\mathrm{CD} 8^{+} \mathrm{T}$ cells may play a role in the first line of defense against protozoan parasites. On the other hand, DN cells, which include NK-like cells and macrophages, did not possess significant cytotoxicity against I. multifiliis, even though these cells are known to possess innate cytotoxic capabilities (Fischer et al., 2013). Theronts have been shown to express a protein similar to chlamydial polymorphic repeatcontaining outer membrane protein, which can suppress the innate immune response and avoid the host immune system (Cassidy-Hanley et al., 2011; Mukura et al., 2017; Tanzer et al., 2001). Thus, the possibility that cytotoxic activities of DN cells are inhibited by $I$. multifiliis protein cannot be excluded. Further studies are warranted to identify additional factors that may be involved in the interaction between hosts and I. multifiliis. 
Recent studies have characterized $\mathrm{CD}^{+}$dendritic cells in rainbow trout mucosal organs, indicating that $\mathrm{CD}^{+}$macrophage/DC cell lineages exist in teleost fish (Soleto et al., 2018). We observed that a few gill effector cells, which were bound to I. multifiliis, were larger than normal lymphocytes; these were, however, not observed in the kidneys. Approximately $5 \%$ of $\mathrm{CD}^{+}$cells were detected in the gating of gill macrophages by flow cytometry analysis, while the percentage of $\mathrm{CD} 8^{+}$cells was less than $1.5 \%$ in the kidney macrophage gating (data not shown). These findings suggest that $\mathrm{CD} 8^{+}$macrophage/DC cells in the gills of ginbuna crucian carp may contribute to the elimination of I. multifiliis, whereas the main effectors were concluded to be $\mathrm{CD} 8^{+}$lymphocytes. $\mathrm{CD}^{+} \mathrm{T}$ cells required direct contact with $I$. multifiliis to exhibit direct cytotoxic activity. In human, anti-parasitic cytotoxic activity of human CTLs is contact-dependent, and supernatants from PHA-stimulated T cells were shown to be incapable of killing the multicellular parasite, S. mansoni (Markham et al., 2020; Mody and Oykhman, 2010). In teleost fish, $\mathrm{CD}^{+} \mathrm{T}$ cells of ginbuna crucian carp previously demonstrated cytotoxic activity against bacteria without contacting the target cells (Tartor et al., 2014). These findings suggest that the cytotoxic mechanism of $\mathrm{CD} 8^{+} \mathrm{T}$ cells of ginbuna carp differs between bacteria and parasites. In the present study, it remains to be determined which type of receptor $\mathrm{CD} 8^{+} \mathrm{T}$ cells are utilized to recognize parasites. On the other hand, NCCs in catfish have the ability to bind to and kill parasites (Graves et al., 1985). Moreover, nonspecific cytotoxic cell receptor protein (NCCRP) in catfish is involved in the recognition of antigens in the mechanism of cytotoxic activity of NCCs (Evans et al., 1998), implying that NCCRP is involved in the recognition of parasites in teleost fish. However, no TCRs for parasites have been found in any fish species. $\mathrm{CD}^{+} \mathrm{T}$ cells from both kidney and gills have been identified as anti-parasitic cytotoxic 
cells, indicating that systemic and local $\mathrm{CD}^{+} \mathrm{T}$ cells possess $\mathrm{CMC}$ against parasites. Theronts attach to and penetrate the host epithelium layer of skin or gills (Dickerson, 2014). $\mathrm{CD}^{+}$lymphocytes are more abundant than neutrophils and macrophages in the skin and gill epithelium and fin cavity of ginbuna crucian carp (unpublished observation). Thus, $\mathrm{CD}^{+}$cells in mucosal tissues first contact the parasite and kill them before the theronts transform to mature trophonts. In contrast, because kidney $\mathrm{CD} 8^{+}$cells also possess anti-parasite cytotoxicity, they are considered to migrate to infectious sites and eliminate the parasites following mucosal resident $\mathrm{CD}^{+}$cells. The gene expression levels of chemokines or chemokine receptors $\mathrm{CXCa}, \mathrm{CXCR} 1, \mathrm{CK} 10, \mathrm{CK} 12$, and CXCR2 were increased in the epidermis of common carp infected with I. multifiliis (Gonzalez et al., 2007; Syahputra et al., 2019). Although it remains unclear whether the chemokines or chemokine receptors act on $\mathrm{CD} 8^{+}$cells or are expressed on $\mathrm{CD} 8^{+}$cells in ginbuna crucian carp, systemic $\mathrm{CD} 8^{+}$cells may be attracted by chemokines secreted from other leukocytes. Further studies are required to reveal which cells or factors attract $\mathrm{CD} 8^{+} \mathrm{T}$ cells to the infectious site. in $\mathrm{CMC}$ and delivers serine proteases to the intracellular portion of pathogen-infected cells (Osińska et al., 2014; Voskoboinik et al., 2015). It has been shown that perforin breaks down the mycobacterial cell wall structure directly and triggers direct cytotoxic activity against bacteria (Lu et al., 2014). Furthermore, perforin and granulysin (GNLY) bind phosphoethanolamine, which is a natural compound essential for transportation and 
localization of the cell wall GPI-anchored proteins in protozoan parasites (Dotiwala and Lieberman, 2019, Ouyang et al., 2019). GPI-anchored proteins play important roles in a variety of biological processes, and deficiency of GPI-anchored proteins results in cell death of trypanosomes in the bloodstream (Simon Lillico et al., 2003). GPI-anchored proteins in the surface membrane of I. multifiliis cells are known as immobilization antigens (i-antigens) (Clark et al., 2001). Antibodies against i-antigens inhibit ciliary beat and cause rapid immobilization of cells in vitro (Dickerson and Findly, 2014). According to these studies, perforin appears to kill I. multifiliis by binding to and deforming GPIanchored proteins. GNLY and NK-lysin (NKL) are potential candidates that may be associated with cytotoxic activity against parasites. GNLY and NKL are member of the saponin-like protein family, are secreted by $\mathrm{CD}^{+} \mathrm{T}$ cells and $\mathrm{NK}$ cells, and have functions in pore formation and granzyme transfer into pathogen-infected cells (Clayberger and Krensky, 2003; Davis et al., 2005; Voskoboinik et al., 2015). Human GNLY demonstrated cytotoxic activity against parasites (Dotiwala et al., 2016; Farouk et al., 2004; Stenger et cytotoxic pathways to kill parasites.

The innate cytotoxicity of $\mathrm{CD}^{+} \mathrm{T}$ cells in the present study demonstrates that the function of innate-like T cells in teleost fish is similar to these cells in other organisms. In mammals, $\mathrm{CD}^{+} \mathrm{T}$ cells and $\gamma \delta \mathrm{T}$ cells demonstrate an immune response against plasmodium 
410 infection (Dantzler and Jagannathan, 2018; Hviid et al., 2019; Kurup et al., 2019).

411 Furthermore, innate-like $\mathrm{CD}^{+} \alpha \beta \mathrm{T}$ cells have been defined in mammals and are

412 identified to be involved in the protection against Staphylococcus aureus and cancer

413 (Barbarin et al., 2017; St. Leger et al., 2018). The existence of innate-like T cells has been

414 suggested in fish, and their features were often found to resemble mammalian innate-like

$415 \gamma \delta$ T cells (Scapigliati et al., 2018). However, although innate-like $\mathrm{CD}^{+} \alpha \beta \mathrm{T}$ cells have

416 not yet been identified in teleost fish, $\mathrm{CD} 8^{+} \gamma \delta \mathrm{T}$ cells in zebrafish are known to possess

417 innate immune functions (Wan et al., 2017). These studies support our hypothesis that

418 teleost innate-like $\mathrm{CD}^{+} \mathrm{T}$ cells play an important role in the initiation of cytotoxic

419 activity against parasites to eliminate them. In addition, innate-like T cells may induce

420 the secretion of inflammatory cytokines and demonstrate phagocytic activity against

421 pathogens. Furthermore, $\gamma \delta \mathrm{T}$ cells also possess antigen-presenting cell functions to

422 activate $\mathrm{CD}^{+}$and $\mathrm{CD}^{+} \mathrm{T}$ cells (Dantzler and Jagannathan, 2018). Therefore, it is

423 conceivable that teleost innate-like $\mathrm{CD}^{+} \mathrm{T}$ cells also present parasitic antigens to

424 conventional $\mathrm{CD}^{+}$and $\mathrm{CD}^{+} \mathrm{T}$ cells to establish secondary immunity. If teleost innate-

425 like $\mathrm{CD}^{+} \mathrm{T}$ cells can generate a secondary response to parasites, understanding their

426 functions might provide a novel insight into developing fish vaccines against parasites.

428 Acknowledgments

429 This work was supported in part by the Japan Society for the Promotion of Science 430 KAKENHI Grant Number JP20H03075, JP17K07939. The authors would like to thank

431 Mr. Masaaki Miyamoto and Dr. Atsushi Sato for supporting the propagation of the 432 parasites. The authors would like to thank Enago (www.enago.jp) for the English 433 language review. 


\section{References}

436 Ahmadpour, E., Ebrahimzadeh, M.A., Sharif, M., Edalatian, S., Sarvi, S., Montazeri, M., Mehrzadi, S., Akbari, M., Rahimi, M.T., Daryani, A., 2019. Anti-Toxoplasma activities of Zea mays and Eryngium caucasicum extracts, in vitro and in vivo. J. Pharmacopuncture 22, 154-159. https://doi.org/10.3831/KPI.2019.22.020

Akula, S., Thorpe, M., Boinapally, V., Hellman, L., 2015. Granule associated serine proteases of hematopoietic cells-an analysis of their appearance and diversification during vertebrate evolution. PLoS One 10, 1-26. https://doi.org/10.1371/journal.pone.0143091

Barbarin, A., Cayssials, E., Jacomet, F., Nunez, N.G., Basbous, S., Lefèvre, L., Abdallah, M., Piccirilli, N., Morin, B., Lavoue, V., Catros, V., Piaggio, E., Herbelin, A., Gombert, J.M., 2017. Phenotype of NK-like CD8(+) T cells with innate features in humans and their relevance in cancer diseases. Front. Immunol. 8, 1-16. https://doi.org/10.3389/fimmu.2017.00316

Barreda, D.R., Hanington, P.C., Stafford, J.L., Belosevic, M., 2005. A novel soluble form of the CSF-1 receptor inhibits proliferation of self-renewing macrophages of goldfish (Carassius auratus L.). Dev. Comp. Immunol. 29, 879-894. https://doi.org/10.1016/j.dci.2005.02.006

Beno, D.W.A., Mathews, H.L., 1992. Growth inhibition of Candida albicans by interleukin-2-activated splenocytes. Infect. Immun. 60, 853-863. https://doi.org/10.1128/iai.60.3.853-863.1992

Beno, D.W.A., Stover, A.G., Mathews, H.L., 1995. Growth inhibition of Candida albicans hyphae by CD8+ lymphocytes. J. Immunol. 154, 5273-5281. 
Buchmann, K., Sigh, J., Nielsen, C. V., Dalgaard, M., 2001. Host responses against the fish parasitizing ciliate Ichthyophthirius multifiliis. Vet. Parasitol. 100, 105-116. https://doi.org/10.1016/S0304-4017(01)00487-3

Cassidy-Hanley, D.M., Cordonnier-Pratt, M.M., Pratt, L.H., Devine, C., Mozammal Hossain, M., Dickerson, H.W., Clark, T.G., 2011. Transcriptional profiling of stage specific gene expression in the parasitic ciliate Ichthyophthirius multifiliis. Mol. Biochem. Parasitol. 178, 29-39. https://doi.org/10.1016/j.molbiopara.2011.04.004

Clark, T.G., Forney, J.D., 2003. Free-living and parasitic ciliates. Antigen. Var. 375402. https://doi.org/10.1016/B978-012194851-1/50042-1

Clark, T.G., Gao, Y., Gaertig, J., Wang, X, C.G., 2001. The I-antigens of Ichthyophthirius multifiliis are GPI-anchored proteins. j eukaryot microbiol 48, 332-337.

Clayberger, C., Krensky, A.M., 2003. Granulysin. Curr. Opin. Immunol. 15, 560-565. https://doi.org/10.1016/S0952-7915(03)00097-9

Coyne, R.S., Hannick, L., Shanmugam, D., Hostetler, J.B., Brami, D., Joardar, V.S., Johnson, J., Radune, D., Singh, I., Badger, J.H., Kumar, U., Saier, M., Wang, Y., Cai, H., Gu, J., Mather, M.W., Vaidya, A.B., Wilkes, D.E., Rajagopalan, V., Asai, D.J., Pearson, C.G., Findly, R.C., Dickerson, H.W., Wu, M., Martens, C., Van de Peer, Y., Roos, D.S., Cassidy-Hanley, D.M., Clark, T.G., 2011. Comparative genomics of the pathogenic ciliate Ichthyophthirius multifiliis, its free-living relatives and a host species provide insights into adoption of a parasitic lifestyle and prospects for disease control. Genome Biol. 12, R100. https://doi.org/10.1186/gb-2011-12-10-r100 
Cross, M.L., Matthews, R.A., 1993. Localized leucocyte response to Ichthyophthirius multifiliis establishment in immune carp Cyprinus carpio L. Vet. Immunol. Immunopathol. 38, 341-358. https://doi.org/10.1016/0165-2427(93)90092-I

Dantzler, K.W., Jagannathan, P., 2018. $\gamma \delta$ T cells in antimalarial immunity: New insights into their diverse functions in protection and tolerance. Front. Immunol. 9, 1-14. https://doi.org/10.3389/fimmu.2018.02445

Davis, E.G., Sang, Y., Rush, B., Zhang, G., Blecha, F., 2005. Molecular cloning and characterization of equine NK-lysin. Vet. Immunol. Immunopathol. 105, 163-169. https://doi.org/10.1016/j.vetimm.2004.12.007

Dickerson, H., Clark, T., 1998. Ichthyophthirius multifiliis: A model of cutaneous infection and immunity in fishes. Immunol. Rev. 166, 377-384. https://doi.org/10.1111/j.1600-065X.1998.tb01277.x

Dickerson, H.W., 2006. Ichthyophthirius multifiliis and Cryptocaryon irritans (phylum Ciliophora), Fish Diseases and Disorders. https://doi.org/10.1079/9780851990156.0116

Dickerson, H.W., Findly, R.C., 2014. Immunity to Ichthyophthirius infections in fish: A synopsis. Dev. Comp. Immunol. 43, 290-299. https://doi.org/10.1016/j.dci.2013.06.004

Dotiwala, F., Lieberman, J., 2019. Granulysin: killer lymphocyte safeguard against microbes. Curr. Opin. Immunol. 60, 19-29. https://doi.org/10.1016/j.coi.2019.04.013

Dotiwala, F., Mulik, S., Polidoro, R.B., Ansara, J.A., Burleigh, B.A., Walch, M., Gazzinelli, R.T., Lieberman, J., 2016. Killer lymphocytes use granulysin, perforin and granzymes to kill intracellular parasites. Nat. Med. 22, 210-216. 

https://doi.org/10.1038/nm.4023

Ellner, J.J., Olds, G.R., Lee, C.W., Kleinhenz, M.E., Edmonds, K.L., 1982. Destruction of the multicellular parasite Schistosoma mansoni by T lymphocytes. J. Clin. Invest. 70, 369-378. https://doi.org/10.1172/JCI110626

Evans, D.L., Leary, J.H., Jaso-Friedmann, L., 1998. Nonspecific cytotoxic cell receptor protein-1: A novel (predicted) type III membrane receptor on the teleost equivalent

Farouk, S.E., Mincheva-Nilsson, L., Krensky, A.M., Dieli, F., Troye-Blomberg, M., 2004. $\gamma \delta$ T cell inhibit in vitro growth of the asexual blood stages of Plasmodium falciparum by a granule exocytosis-dependent cytotoxic pathway that requires granulysin. Eur. J. Immunol. 34, 2248-2256. https://doi.org/10.1002/eji.200424861

Fischer, U., Koppang, E.O., Nakanishi, T., 2013. Teleost T and NK cell immunity. Fish Shellfish Immunol. 35, 197-206. https://doi.org/10.1016/j.fsi.2013.04.018

Gonzalez SF, Buchmann K, Nielsen ME. Real-time gene expression analysis in carp (Cyprinus carpio L.) skin: inflammatory responses caused by the ectoparasite Ichthyophthirius multifiliis. 2007 Fish Shellfish Immunol. 22, 641-50. doi: 10.1016/j.fsi.2006.08.011.

Graves, S.S., Evans, D.L., Dawe, D.L., 1985. Antiprotozoan activity of nonspecific cytotoxic cells (NCC) from the channel catfish (Ictalurus punctatus). J. Immunol. $134,78-85$.

Hong, Y.H., Lillehoj, H.S., Siragusa, G.R., Bannerman, D.D., Lillehoj, E.P., 2008. Antimicrobial Activity of Chicken NK-Lysin Against Eimeria Sporozoites. Avian Dis. Dig. 3, e16-e16. https://doi.org/10.1637/8324-808308-digest.1 
Huang, Y., Zheng, Q., Niu, J., Tang, J., Wang, B., Abarike, E.D., Lu, Y., Cai, J., Jian, J., 2018. NK-lysin from Oreochromis niloticus improves antimicrobial defence against bacterial pathogens. Fish Shellfish Immunol. 72, 259-265. https://doi.org/10.1016/j.fsi.2017.11.002

Hviid, L., Smith-Togobo, C., Willcox, B.E., 2019. Human V81+T cells in the immune response to plasmodium falciparum infection. Front. Immunol. 10. https://doi.org/10.3389/fimmu.2019.00259

Jaso-Friedmann, L., Leary, J.H., Warren, J., McGraw, R.A., Evans, D.L., 1997. Molecular characterization of a protozoan parasite target antigen recognized by nonspecific cytotoxic cells. Cell. Immunol. 176, 93-102. https://doi.org/10.1006/cimm.1996.1063

Kurup, S.P., Butler, N.S., Harty, J.T., 2019. T cell-mediated immunity to malaria. Nat. Rev. Immunol. 19, 457-471. https://doi.org/10.1038/s41577-019-0158-z

Lama, R., Pereiro, P., Costa, M.M., Encinar, J.A., Medina-Gali, R.M., Pérez, L., Lamas, J., Leiro, J., Figueras, A., Novoa, B., 2018. Turbot (Scophthalmus maximus) Nklysin induces protection against the pathogenic parasite Philasterides dicentrarchi via membrane disruption. Fish Shellfish Immunol. 82, 190-199. https://doi.org/10.1016/j.fsi.2018.08.004

Lu, C.-C., Wu, T.-S., Hsu, Y.-J., Chang, C.-J., Lin, C.-S., Chia, J.-H., Wu, T.-L., Huang, T.-T., Martel, J., Ojcius, D.M., Young, J.D., Lai, H.-C., 2014. NK cells kill mycobacteria directly by releasing perforin and granulysin. J. Leukoc. Biol. 96, 1119-1129. https://doi.org/10.1189/jlb.4a0713-363rr

Markham, R.B., Goellner. J., Pier, G.B., 1984. In vitro T cell-mediated killing of Pseudomonas aeruginosa. I. Evidence that a lymphokine mediates killing. J. 
Matsuura, Y., Yabu, T., Shiba, H., Moritomo, T., Nakanishi, T., 2014. Identification of a novel fish granzyme involved in cell-mediated immunity. Dev. Comp. Immunol. 46, 499-507. https://doi.org/10.1016/j.dci.2014.06.006

Miyazawa, R., Murata, N., Matsuura, Y., Shibasaki, Y., Yabu, T., Nakanishi, T., 2018. Peculiar expression of CD3-epsilon in kidney of ginbuna crucian carp. Front. Immunol. 9. https://doi.org/10.3389/fimmu.2018.01321

Mody, C.H., Oykhman, P., 2010. Direct microbicidal activity of cytotoxic Tlymphocytes. J. Biomed. Biotechnol. 2010. https://doi.org/10.1155/2010/249482

Mukura, L.R., Hickey, D.K., Rodriguez-Garcia, M., Fahey, J. V., Wira, C.R., 2017. Chlamydia trachomatis regulates innate immune barrier integrity and mediates cytokine and antimicrobial responses in human uterine ECC-1 epithelial cells. Am. J. Reprod. Immunol. 78, 1-11. https://doi.org/10.1111/aji.12764

Nayak, S.K., Nakanishi, T., 2013. Direct antibacterial activity of CD8+/CD4+ T-cells in ginbuna crucian carp, Carassius auratus langsdorfii. Fish Shellfish Immunol. 34, 136-141. https://doi.org/10.1016/j.fsi.2012.10.016

Nonaka, S., Somamoto, T., Kato-Unoki, Y., Ototake, M., Nakanishi, T., Nakao, M., 2008. Molecular cloning of CD4 from ginbuna crucian carp Carassius auratus langsdorfii. Fish. Sci. 74, 341-346. https://doi.org/10.1111/j.14442906.2008.01530.x

Olsen, M.M., Kania, P.W., Heinecke, R.D., Skjoedt, K., Rasmussen, K.J., Buchmann, K., 2011. Cellular and humoral factors involved in the response of rainbow trout gills to Ichthyophthirius multifiliis infections: Molecular and immunohistochemical studies. Fish Shellfish Immunol. 30, 859-869. 
Osińska, I., Popko, K., Demkow, U., 2014. Perforin: An important player in immune response. Cent. Eur. J. Immunol. 39, 109-115. https://doi.org/10.5114/ceji.2014.42135

Ouyang, H., Du, T., Zhou, H., Wilson, I.B.H., Yang, J., Latgé, J.P., Jin, C., 2019. Aspergillus fumigatus phosphoethanolamine transferase gene gpi7 is required for proper transportation of the cell wall GPI-anchored proteins and polarized growth. Sci. Rep. 9, 1-12. https://doi.org/10.1038/s41598-019-42344-1

Salata, R.A., Cox, J.G., Ravdin, J.I., 1987. The interaction of human T-Iymphocytes and Entamoeba histolytica: killing of virulent amoebae by lectin-dependent lymphocytes. Parasite Immunol. 9, 249-261. https://doi.org/10.1111/j.13653024.1987.tb00504.x

Scapigliati, G., Fausto, A.M., Picchietti, S., 2018. Fish lymphocytes: An evolutionary equivalent of mammalian innate-like lymphocytes? Front. Immunol. 9, 1-8. https://doi.org/10.3389/fimmu.2018.00971

Simon Lillico, M.C.F., Pat Blundell, Graham H. Coombs, and J.C.M., 2003. Essential Roles for GPI-anchored Proteins in African Trypanosomes Revealed Using Mutants Deficient in GPI8. Mol. Biol. Cell 14, 1182-1194. https://doi.org/10.1091/mbc.E02

Soleto, I., Fischer, U., Tafalla, C., Granja, A.G., 2018. Identification of a potential common ancestor for mammalian cross-presenting dendritic cells in teleost respiratory surfaces. Front. Immunol. 9, 1-13. https://doi.org/10.3389/fimmu.2018.00059 Somamoto, T., Koppang, E.O., Fischer, U., 2014. Antiviral functions of CD8+ 
602

603

604

605

606

607

608

609

610

611

612

613

614

615

616

617

618

619

620

621

622

623

624

625

cytotoxic T cells in teleost fish. Dev. Comp. Immunol. 43, 197-204. https://doi.org/10.1016/j.dci.2013.07.014

Somamoto, T., Miura, Y., Nakanishi, T., Nakao, M., 2015. Local and systemic adaptive immune responses toward viral infection via gills in ginbuna crucian carp. Dev. Comp. Immunol. 52, 81-87. https://doi.org/10.1016/j.dci.2015.04.016

Somamoto, T., Yoshiura, Y., Sato, A., Nakao, M., Nakanishi, T., Okamoto, N., Ototake, M., 2006. Expression profiles of TCR $\beta$ and CD8 $\alpha$ mRNA correlate with virusspecific cell-mediated cytotoxic activity in ginbuna crucian carp. Virology 348, 370-377. https://doi.org/10.1016/j.virol.2006.01.019

St. Leger, A.J., Hansen, A.M., Karauzum, H., Horai, R., Yu, C.R., Laurence, A., MayerBarber, K.D., Silver, P., Villasmil, R., Egwuagu, C., Datta, S.K., Caspi, R.R., 2018. STAT-3-independent production of IL-17 by mouse innate-like $\alpha \beta$ T cells controls ocular infection. J. Exp. Med. 215, 1079-1090. https://doi.org/10.1084/jem.20170369

Stenger, S., Hanson, D.A., Teitelbaum, R., Dewan, P., Niazi, K.R., Froelich, C.J., Ganz, T., Thoma-Uszynski, S., Melián, A., Bogdan, C., Porcelli, S.A., Bloom, B.R., Krensky, A.M., Modlin, R.L., 1998. An antimicrobial activity of cytolytic T cells mediated by granulysin. Science (80-. ). 282, 121-125. https://doi.org/10.1126/science.282.5386.121

Sun, H.Y., Zhu, X.Q., Xie, M.Q., Wu, X.Y., Li, A.X., Lin, R.Q., Song, H.Q., 2006. Characterization of Cryptocaryon irritans isolates from marine fishes in Mainland China by ITS ribosomal DNA sequences. Parasitol. Res. 99, 160-166. https://doi.org/10.1007/s00436-006-0151-x

Syahputra, K., Kania, P.W., Al-Jubury, A., Marnis, H., Setyawan, AC., Buchmann, K., 
2019. Differential immune gene response in gills, skin, and spleen of rainbow trout Oncorhynchus mykiss infected by Ichthyophthirius multifiliis. PLoS One. 20;14(6):e0218630. doi: 10.1371/journal.pone.0218630. eCollection 2019.

Tanzer, R.J., Longbottom, D., Hatch, T.P., 2001. Identification of polymorphic outer membrane proteins of Chlamydia psittaci 6BC. Infect. Immun. 69, 2428-2434. https://doi.org/10.1128/IAI.69.4.2428-2434.2001

Tartor, H.M., Matsuura, Y., El-Nobi, G., Nakanishi, T., 2014. Lack of a contact requirement for direct antibacterial activity of lymphocyte subpopulations in ginbuna crucian carp. Fish Shellfish Immunol. 39, 178-184. https://doi.org/10.1016/j.fsi.2014.05.006

Toda, H., Araki, K., Moritomo, T., Nakanishi, T., 2011a. Perforin-dependent cytotoxic mechanism in killing by CD8 positive T cells in ginbuna crucian carp, Carassius auratus langsdorfii. Dev. Comp. Immunol. 35, 88-93. https://doi.org/10.1016/j.dci.2010.08.010

Toda, H., Saito, Y., Koike, T., Takizawa, F., Araki, K., Yabu, T., Somamoto, T., Suetake, H., Suzuki, Y., Ototake, M., Moritomo, T., Nakanishi, T., 2011 b. Conservation of characteristics and functions of CD4 positive lymphocytes in a teleost fish. Dev. Comp. Immunol. 35, 650-660. https://doi.org/10.1016/j.dci.2011.01.013

Toda, H., Shibasaki, Y., Koike, T., Ohtani, M., Takizawa, F., Ototake, M., Moritomo, T., Nakanishi, T., 2009. Alloantigen-specific killing is mediated by CD8-positive T cells in fish. Dev. Comp. Immunol. 33, 646-652. https://doi.org/10.1016/j.dci.2008.11.008

Toda, H., Yabu, T., Shiba, H., Moritomo, T., Nakanishi, T., 2011c. Evaluating antigen- 
specific cytotoxicity of CD8+ T cells in fish by granzyme B-like activity. Vet. Immunol. Immunopathol. 141, 168-172. https://doi.org/10.1016/j.vetimm.2011.02.020

Von Gersdorff Jørgensen, L., Heinecke, R.D., Skjødt, K., Rasmussen, K.J., Buchmann, K., 2011. Experimental evidence for direct in situ binding of $\operatorname{IgM}$ and $\operatorname{Ig} \mathrm{T}$ to early trophonts of Ichthyophthirius multifiliis (Fouquet) in the gills of rainbow trout, Oncorhynchus mykiss (Walbaum). J. Fish Dis. 34, 749-755. https://doi.org/10.1111/j.1365-2761.2011.01291.x

Voskoboinik, I., Whisstock, J.C., Trapani, J.A., 2015. Perforin and granzymes: Function, dysfunction and human pathology. Nat. Rev. Immunol. 15, 388-400. https://doi.org/10.1038/nri3839

Wan, F., Hu, C. Bin, Ma, J.X., Gao, K., Xiang, L.X., Shao, J.Z., 2017. Characterization of $\gamma \delta \mathrm{T}$ cells from zebrafish provides insights into their important role in adaptive humoral immunity. Front. Immunol. 7. https://doi.org/10.3389/fimmu.2016.00675

Wang, Q., Yu, Y., Zhang, X., Xu, Z., 2019. Immune responses of fish to Ichthyophthirius multifiliis (Ich): A model for understanding immunity against protozoan parasites. Dev. Comp. Immunol. 93, 93-102. https://doi.org/10.1016/j.dci.2019.01.002

Xu, D.H., Klesius, P.H., Shelby, R.A., 2004. Immune responses and host protection of channel catfish, Ictalurus punctatus (Rafinesque), against Ichthyophthirius multifiliis after immunization with live theronts and sonicated trophonts. J. Fish Dis. 27, 135-41. doi: 10.1111/j.1365-2761.2004.00523.x.

Xu, D.H., Klesius, P.H., 2013. Comparison of serum antibody responses and host protection against parasite Ichthyophthirius multifiliis between channel catfish and 
Xu, D.H., Klesius, P.H., Shoemaker, C.A., 2009. Effect of immunization of channel catfish with inactivated trophonts on serum and cutaneous antibody titers and survival against Ichthyophthirius multifiliis. Fish Shellfish Immunol. 26, 614-618. https://doi.org/10.1016/j.fsi.2008.09.015

Yamaguchi, T., Takizawa, F., Furihata, M., Soto-Lampe, V., Dijkstra, J.M., Fischer, U., 681 2019. Teleost cytotoxic T cells. Fish Shellfish Immunol. 95, 422-439.

Yamasaki, M., Araki, K., Nakanishi, T., Nakayasu, C., Yamamoto, A., 2014. Role of $\mathrm{CD} 4+$ and $\mathrm{CD} 8 \alpha+\mathrm{T}$ cells in protective immunity against Edwardsiella tarda infection of ginbuna crucian carp, Carassius auratus langsdorfii. Fish Shellfish Immunol. 36, 299-304. https://doi.org/10.1016/j.fsi.2013.11.016 of teleost fish against parasitic infection. PLoS Pathog. 14, 1-24. https://doi.org/10.1371/journal.ppat.1007251

Figure legends 695

Figure 1. Expression profile of $\mathrm{T}$ cell markers in MACS-sorted leukocytes from the kidney and gill cells of ginbuna crucian carp. DN indicates CD8 and CD4 double-negative lymphocytes; NC indicates non-template control. EF1 $\alpha$ was used as an internal control. Numbers to the right indicate PCR cycles. Data from one fish are shown as representative 
of the three fish analyzed.

Figure 2. Time course of cytotoxic activity of kidney (A) and gill (B) leukocytes against I. multifiliis. Kidney and gill leukocytes from naïve ginbuna crucian carp were incubated with I. multifiliis at various E:T ratios (2000:1, 1000:1, 300:1, and 100:1). Data from one fish are shown as representative of the three fish analyzed.

Figure 3. Cytotoxic activity of unsorted and sorted effector cells from the kidneys (A) and gills (B) against I. multifiliis. The mean activities of $\mathrm{CD} 4^{+}$cells, $\mathrm{CD} 8^{+}$cells, DN cells, and unsorted cells are shown (gill, $n=3$; kidney, $n=4$ ). The effector cells were incubated for $2 \mathrm{~h}$ with I. multifiliis at E:T ratio of 1000:1. Error bars indicate SD. Different letters on each bar indicate significant differences among the groups $(\mathrm{P}<0.05)$.

Figure 4. Contact of $\mathrm{CD}^{+}$cells from the kidneys and gills to the surface of I. multifiliis. Arrows indicate $\mathrm{CD}^{+}$cells (red) and I. multifiliis (green). Kidney leukocytes and $I$. multifiliis are shown in the upper panels (A, B, C). Scale bars indicate $10 \mu \mathrm{m}$.

Figure 5. Cytotoxic activity of the effector cells from the kidney (A and B) and the gill (C and D) against I. multifiliis with or without the culture insert. $\mathrm{CD} 8^{+}$cells (A and C) and $\mathrm{CD} 8^{-}$cells (B and D) were used as the effector cells. $\mathrm{CD} 8^{+}$cells were co-cultured with I. multifiliis at E:T ratio of 500:1. The results from the three individual fish are shown as the mean of cell killing activities. White and black bars indicate the activities of the effector cells in the absence (contact) and presence (non-contact) of the insert, respectively. The asterisks indicate significant differences of the activities between non- 
contact and contact $(* \mathrm{P}<0.05)$.

723

724 Figure 6. Effect of DCI on the cytotoxic activity of $\mathrm{CD}^{+}$cells from the kidney (A) and 725 the gill (B). $\mathrm{CD}^{+}$cells were pre-incubated with various concentrations $(0,20,40 \mu \mathrm{M})$ of 726 DCI. CD8 ${ }^{+}$cells were co-cultured with I. multifiliis at E:T ratio of 300:1. Data are shown 727 as the means of the activities from three (kidney) or four (gill) individual fish, respectively. 728 Error bars indicate SD. Asterisks indicate significant differences from control group (0 $729 \mu \mathrm{M})(\mathrm{P}<0.05)$.

730

731 Figure 7. Effect of CMA on the cytotoxic activity of $\mathrm{CD}^{+}$cells from the kidney (A) and 732 the gill $(\mathrm{B}) . \mathrm{CD}^{+}$cells were pre-incubated with various concentrations $(0,0.5,1.0 \mu \mathrm{M})$ 733 of CMA. $\mathrm{CD}^{+}$cells were co-cultured with I. multifiliis at E:T ratio of 300:1. Data are 734 shown as means of the activities from three (kidney) or four (gill) individual fish. Error 735 bars indicate SD. Asterisks indicate significant differences from control group $(0 \mu \mathrm{M})(\mathrm{P}$ $736<0.05)$ 